\title{
Exploration of Transfer of Control Rights of the Largest Shareholder
}

\author{
Xiaojun Deng \\ School of Economics and Management \\ Xi'an Shiyou University \\ Xi'an, Shaanxi Province, 710065 \\ dxj0624@126.com
}

\author{
Qing $\mathrm{Yu}$ \\ School of Economics and Management \\ Xi'an Shiyou University \\ Xi'an, Shaanxi Province, 710065
}

\begin{abstract}
After the completion of the split share reform, which aims to coordinate the interests of the shareholders, improve the corporate governance mechanism and maintain the long-term development of the capital market, China's capital market has entered the full circulation era. However, under the background of full circulation, China's "listed companies' equity concentration anomalies" have not been fundamentally relieved, while the largest shareholders have lost their holding position in the capital market. Thus, a new round of "vision of transfer of the control right of the first largest shareholders" emerged. On the basis of combing and analyzing the existing research literature system at home and abroad, the empirical findings of the transfer of control rights of first largest shareholder in the A stock market of China from 2012 to 2016 are found: after full circulation, the transfer control rights of first largest shareholder is still serious; the first largest shareholder of listed companies involved in the transfer of control rights is the computer, communications and other electronic equipment manufacturing industry, followed by the electrical machinery and equipment manufacturing industry; corporate inves tors, other corporate investors, and public shares (circulating A shares) investors account for the majority of the shares transferred by the first largest shareholder of the listed company; Judging from the nature of the company, private enterprises are more vulnerable to the transfer of control of the first largest shareholder. This rese arch conclusion provides a new perspective for governance of the "vision of transfer of control rights of first largest shareholder" in different industries.
\end{abstract}

Keywords-Full circulation; First largest shareholder; Transfer of control

\section{INTRODUCTION}

Since Baoan Co., Ltd. acquired the first control rights transfer event in Yanzhong Industry in September 1993, the transfer of control rights of listed companies has become increasingly fierce in China's capital market. Under China's highly concentrated equity structure, the transfer of control rights of listed companies is undoubtedly closely related to the development of China's capital market. On the whole, the development of China's capital market has undergone two stages: the split period of equity before the split share structure reform and the later phase of the split share structure reform. In the first stage, tradable shares and non-tradable coexist in the capital market, but the division of equities triggers the existence of differences in interest mechanisms between

Fund Project:The Research Achievements of "The Stealth Financial Capital Research of Corporate Finance" (Project number: 0109-290088283) Supported by Xi'an Shiyou University High-level Talent Support Project. tradable shareholders and non-tradable shareholders. From 2006 to 2012, although the equity division reform has been completed, the existence of a large number of restricted shares on the capital market has led to serious "non-tradable share" problems. After 2012, the lifting of the ban on share sale reforms has reached about $98 \%$. The equity splitting issue and the "non-tradable share" issue have basically eliminated the impact on the capital market. China's capital market has really entered the era of full circulation.

After full circulation, with the improvement of the information disclosure system of the capital market and the tightening of the management of the supervisory departments, has the first largest shareholder obtained private benefits of control rights in the process of changing and transferring control rights[1]? Is the transfer of control accompanied by changes in management? Can a first largest shareholder also influence the decision of the board of directors by electing "owner" as a director and making them "interest advocate"[2]? In a highly concentrated equity structure, what measures will management take to respond to changes in the first largest shareholder and the resulting transfer of control rights [3]? The core of the above issues involves the transfer of control rights of the first largest shareholder. Based on this, this paper intends to carry out an innovative discussion on the status quo and industry characteristics of the first largest shareholder control transfer.

\section{After the Share Reform, the CurRent Situation of REDUCTION OF SHAREHOLDERS WITH MORE THAN 5\% SHAREHOLDING IN THE A STOCK MARKET AFTER THE SHARE REFORM SINCE 2007}

It has been 10 years since the split share structure reform. During this decade, there is a strange stage in our capital market: regardless of the growth trend and the expectations of the real economy, and regardless of whether the broader market rises, the large shareholders in the capital market always reduce little shares in a listed company when occurring small rises and large shares in a listed company when occurring large rises. The important shareholder of a listed company, which should have stabilized the capital market and stabilized the real economy, has become a "cutting vanguard" in the capital market. With respect to the above-mentioned laws and regulations promulgated by the regulatory authorities to restrict the reduction of large shareholders, some of them are 
maximizing shareholdings while complying with regulations. What's more, some of the major shareholders have also violated regulations. According to the selected database information, from 2007 to 2016, an important shareholder in China's stock market has experienced net reductions for 10 consecutive years[4](ie: shareholders with disclosure of information disclosure obligations like more than 5\% of major shareholders holding shares and shareholders with disclosure of information disclosure obligations).

The assumption of the equity split reform system is to change the situation of splitting of equity in China's capital market and to break the barriers of interest between circulating shareholders and non-tradable shareholders. At that time, system designers designed a restriction period in order to reduce the impact of non-tradable shareholders on the market after they had currency vouchers. However, from the actual status quo, the limited sales period does not play a real "restricted" role for the reduction of large shareholders. Wu Xiaoqiu et al. [5] (2006), after analyzing the sequential game model and the simultaneous decision static game model, believe that the equilibrium game that is more likely to occur after the lifting of restricted shares is the reduction of holding; $\mathrm{Wu}$ Yuhui et al. [6] (2012) believe that the non-tradable share reduction after shareholding structure reform is the optimal decision-making behavior of shareholders under the influence of internal and external factors of the company. Since September 2006, Weixing Group's holding of restricted shares of Weixing shares has been lifted after the partial lifting of the ban, and as non-restricted holdings of unlisted shares have been lifted, the reduction of non-tradable shares has become more common.

From the perspective of the shareholding structure reform and the timetable for lifting the ban on circulation of restricted shares, by the end of 2006, the split share structure reform was basically completed, the scale of lifted bans on share sale reforms reached the maximum from 2007 to 2009, and by the end of 2011, most of the restricted-sale stocks arising from the share-trading reform have been released from circulation, and it should be said that the issue of restricted shares arising from the reform of non-tradable shares, or the effect of a "nontradable share” reduction on capital markets, has been basically eliminated. According to the author's collection of information in the choice database, the impact of the "non-tradable share" reduction on the capital market has been basically eliminated, and the pace of shareholder reductions has not slowed down. In 2015, it reached the peak of reduction of large shareholders since the reform of the equity division reform, and the amount of reductions reached as high as 217.05 billion Yuan.

TABLE I. 2012-2016 CHINA A SHARE MARKET MAJOR SHAREHOLDERS REDUCTION ST ATIST ICS

\begin{tabular}{|c|c|c|c|}
\hline Year & $\begin{array}{c}\text { Reduction in holdings of large shareholders (unit: } \\
\text { 100 million shares) }\end{array}$ & $\begin{array}{c}\text { Reduction in market value of large shareholders } \\
\text { (unit: 100 million Yuan) }\end{array}$ & $\begin{array}{c}\text { Reduction in the number of shares } \\
\text { held ring over the growth rate }\end{array}$ \\
\hline 2011 & 50.76 & 771.61 & \\
\hline 2012 & 16.07 & 444.16 & \\
\hline 2013 & 68.14 & 1111.66 & \\
\hline 2014 & 61.8 & 1468.25 & \\
\hline 2015 & 164.11 & 2170.5 & \\
\hline 2016 & 35.91 & 1103.9 & $32.44 \%$ \\
\hline
\end{tabular}

\section{Statistical Analysis of TRAnsfer of Control Rights} OF THE FIRST LARGE SHAREHOLDER AFTER FULL

\section{CIRCULATION}

In this paper, after excluding the sample that is not relevant to the research objectives, mainly through the transfer of control rights in five ways of state-owned assets free allocation, divorce share segregation, inheritance, judicial adjudication and judicial auction, there are 152 remaining sample enterprises during the period 2012-2016. The basic situation of control transfer of these sample enterprises is as follows:

\section{A. The Industry Characteristics of the Transfer of Control Rights of the First Largest Shareholder}

According to the statistical classification of national economic industry classification and code (GB/4754-2011), the listed company with the transfer of control rights of the largest shareholder involved 42 industries. In terms of quantity, the largest number of listed companies involved in the transfer of the first major shareholder control is computer, communications and other electronic equipment manufacturing industries, involving 21 companies, followed by electrical machinery and equipment manufacturing, involving 17 companies. There are 1 listed companies involved in the transfer of control of the largest shareholder in waste resource comprehensive utilization industry, ferrous metal mining and dressing industry, education, mining auxiliary activities, forestry, coal mining and washing industry, agriculture, forestry, animal husbandry and fishing service industry, electrical machinery and equipment manufacturing, other manufacturing industries, automobile manufacturing industry, ecological protection and environmental governance, petroleum processing coking and nuclear fuel processing industry, water transportation industry, culture and arts industry, instrument manufacturing industry, professional technical service, and comprehensive industries and so on.

TABLE II. THE DIST RIBUTION OF MAJOR INDUST RIES OF LISTED COMPANIES IN THE TRANSFER OF CONT ROL RIGHTS OF THE FIRST LARGEST SHAREHOLDER

\begin{tabular}{|c|c|c|c|}
\hline No. & Industry & $\begin{array}{c}\text { Number of listed } \\
\text { companies involved }\end{array}$ & 2 \\
\hline 1 & Storage industry & 3 & $1.32 \%$ \\
\hline 2 & Electricity, heat production and supply & $1.97 \%$ \\
\hline 3 & Electrical machinery and equipment manufacturing & 17 & $11.18 \%$ \\
\hline
\end{tabular}




\begin{tabular}{|c|c|c|c|}
\hline \multicolumn{4}{|c|}{ Cont. to TABLE II } \\
\hline 4 & Real estate industry & 6 & $3.95 \%$ \\
\hline 5 & Clothing, textiles and apparel industry & 7 & $4.61 \%$ \\
\hline 6 & Non-metallic mineral products industry & 5 & $3.29 \%$ \\
\hline 7 & Radio, television and film industry & 2 & $1.32 \%$ \\
\hline 8 & Internet and related services & 2 & $1.32 \%$ \\
\hline 9 & Chemical raw materials and chemical products manufacturing & 8 & $5.26 \%$ \\
\hline 10 & Computers, communications and other electronic devices & 21 & $13.82 \%$ \\
\hline 11 & Architectural decoration and other construction & 3 & $1.97 \%$ \\
\hline 12 & Wine, beverages and refined tea industry & 3 & $3.95 \%$ \\
\hline 13 & Retail and wholesale & 6 & $1.32 \%$ \\
\hline 14 & Gas production and supply & 2 & $5.92 \%$ \\
\hline 15 & Software and information technology services & 9 & $1.97 \%$ \\
\hline 16 & Business services & 3 & $1.97 \%$ \\
\hline 17 & Railways, ships, aerospace and other transport equipment & 3 & $2.63 \%$ \\
\hline 18 & manufacturing & 4 & $1.32 \%$ \\
\hline 19 & General equipment manufacturing & 2 & $5.92 \%$ \\
\hline 20 & Rubber and plastic products & 9 & $3.95 \%$ \\
\hline 21 & Pharmaceutical manufacturing & 6 & $5.26 \%$ \\
\hline 22 & Non-ferrous metal mining, non-ferrous metal smelting and & & $1.32 \%$ \\
\hline 23 & pressure extension & 2 & $12.50 \%$ \\
\hline 24 & Special equipment manufacturing & 19 & $1.32 \%$ \\
\hline
\end{tabular}

Source: CN information, GTA and CSMAR Database

The capital market shares can be split into national shares (A share formed by investment of a department or an investment institution that has the right to represent a state to a company), legal person shares (a share formed by investment of an enterprise legal person, institution and social organization with legal person qualification to listed companies with disposable assets), social public shares (trading A shares) and foreign shares according to their nature. Judging from the nature of the shares involved in the transfer of control rights of the first largest shareholder of 152 listed companies from 2012 to 2016, there are 30 legal person holding shares, accounting for $19.73 \%$, 3 state-owned corporate shares, accounting for $1.97 \%$ and 27 other legal person shares, accounting for 17.76 . 113 A-share and social public stocks accounted for $74.34 \%$; 9 foreign-funded stocks (overseas legal person shares) accounted for $5.93 \%$. From the above data, it can be seen that corporate investors, other corporate investors, and social public shares (trading A shares) investors account for the majority of shares transferred by the first largest shareholder of the listed company. This may be due to the following reasons: the first one is capital profit. The majority of other corporate shareholders and natural person shareholders belong to the founder of the company. After initial business start-up, product innovation, and management innovation, the company has grown and expanded. Finally, it has made the company go public through capital operations, and has made huge profits. After a certain period of operation, the company entered a bottleneck period of development, and this type of shareholder no longer had the enthusiasm of the beginning of the venture, and initiated the idea of taking profits and then leaving. The second is the normal capital withdrawal. This kind of funds is generally an investment fund. At the beginning, they were optimistic about the project and invested capital. In the latter capital market, due to various reasons, they became the first largest shareholder themselves. However, such shareholders are essentially financial capital, so choosing the right to withdraw is its capital nature. Third, as the first largest shareholder, compared with other shareholders, they have more information on the company's production and operation. When the company's operations have encountered operational difficulties or other risks, they chose to escape to reduce risks rationally.

\section{B. Analysis of the Nature of Listed Companies Involved in the Transfer of Control Rights of the First Largest Shareholder}

From the nature of the listed companies involved in the transfer of control rights of the first major shareholders, the state owned enterprises accounted for 20, accounting for $13.16 \%$, private enterprises accounted for 127 , accounting for $83.55 \%$, and foreign enterprises accounted for 5 , accounting for $3.29 \%$

TABLE III. STATISTICS ON THE NATURE OF LISTED COMPANIES INVOLVING THE TRANSFER OF CONT ROL RIGHTS OF THE FIRST LARGEST SHAREHOLDER

\begin{tabular}{|c|c|c|}
\hline Nature of listed company & Number & Percentage \\
\hline State-owned enterprises & 20 & $13.16 \%$ \\
\hline Private enterprise & 127 & $83.55 \%$ \\
\hline Foreign enterprise & 5 & $3.29 \%$ \\
\hline Total & 152 & \\
\hline \multicolumn{2}{|c|}{ Source: CN information, GTA and CSMAR Database }
\end{tabular}

\section{Distribution Statistics of the Transfer Time of the Control Rights of the First Largest Shareholder}

From the time of transfer of control rights, there are 5 companies in 2012, accounting for 3.29\%; 13 companies in 2013, accounting for 8.55\%; 29 companies in 2014, accounting for $19.08 \%$; 59 companies in 2015, accounting for 38.82\%; and 46 companies in 2012 , accounting for $30.26 \%$. The time for the transfer of control rights of the largest shareholder occurred mainly from 2014 to 2016. Especially in 2015, the largest shareholder held the largest number of changes in control rights, accounting for the largest proportion. During the period, the 
unlisted share sale reform has basically lifted the ban on the sale of shares, and the effect of the "non-tradable share" problem caused by the split share structure reform has basically eliminated the reduction of the largest shareholder, however, the phenomenon of reduction of holdings by largest shareholders and transfer of control rights by the largest shareholder is still serious.

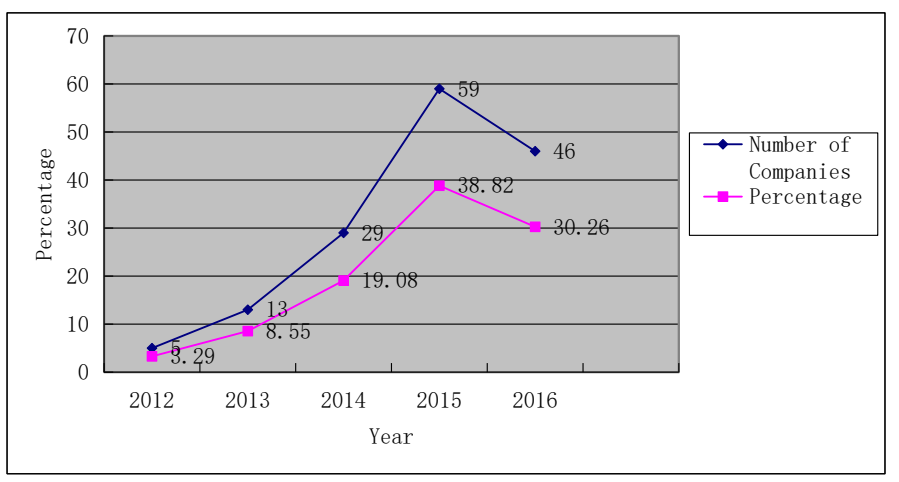

Fig. 1. Time and Percentage of Transfer of Control Rights by the Largest Shareholders

\section{CONCLUSION}

1. As a whole, after the equity division reform, the majority shareholders holding more than 5\% of shares still held back a lot of holdings of shares. Some of the largest shareholder even transferred control rights and changed the status of the largest shareholder.
2. After full circulation, the restricted share sale reform has basically lifted the ban, but the transfer of control rights by the largest shareholder is still serious.

3. The largest number of listed companies in the first largest shareholders' control rights is computer, communications and other electronic equipment manufacturing industries, followed by electrical machinery and equipment manufacturing. Legal investors, other corporate investors and public shares (circulating A shares) Investors occupy the majority of the shares transferred by the largest shareholder of the listed company; from the perspective of the company's nature, private enterprises are more prone to the transfer of control rights of the largest shareholder;

\section{REFERENCES}

[1] Faccio M and Lang L H P. The ultimate ownership of western European corporations[J]. Journal of Financial Economics, 2002, 65(3):365-395.

[2] Holderness C G. The myth of diffuse ownership in the United States [J].Review of financial studies, 2009, 22(4):1377-1408.

[3] Robert. F. Bruner, Does M\&A pay a survey of evidence for the decision maker[J].Journal of Applied finance,2002(12):48-69.

[4] Tang Yingkai, Su Shaomin \& Yang Anhua. Legal Environment and Transfer of Control Rights: A Perspective of Law and Finance [J].Journal of Sichuan University (Philosophy and Social Sciences Edition), 2013(6):116-125.

[5] Wu Xiaoqiu. China's Capital Market after the Share Split Reform [M]. Beijing: China Renmin University Press, 2006.

[6] Wu Yuhui. A Study on the New Short Selling Behavior of the First Large Shareholder after the Share Split Reform [M]. Beijing: Peking University Press, 2012. 